\title{
BIOPLYNOVÉ STANICE VE VENKOVSKÉM PROSTORU: POZNÁMKY K JEJICH AKCEPTACI MÍSTNÍM OBYVATELSTVEM
}

ANAEROBIC DIGESTION PLANTS IN RURAL SPACE: SOME COMMENTS ON THEIR ACCEPTANCE AT COMMUNITY LEVEL

Mgr. Stanislav MARTINÁT ${ }^{1}$

BC. VERONIKA MELNÍKOVÁ 1

Mgr. Petr DVOŘÁK, PH.D. ${ }^{2}$

Mgr. Petr KLUSÁČEK, Ph.D. ${ }^{3}$

RNDr. Josef NAVRÁTIL, Ph.D. ${ }^{4}$

Drs. DAN VAN DER HORST, PH.D. ${ }^{5}$

${ }^{1}$ Obchodně podnikatelská fakulta v Karviné ${ }^{1}$ Silesian University in Opava

Slezská univerzita v Opavě School of Business Administration in Karvina

$\triangle$ Univerzitní náměstí 1934/3, 73340 Karviná, Czech Republic

E-mail: martinat@opf.slu.cz

${ }^{2}$ Odděleni environmentální geografie ${ }^{2}$ Department of Environmental Geography

Ústav geoniky AV ČR Institute of Geonics, Academy of Sciences of the CR

$\bowtie$ Studentská 1768708 00, Ostrava, Czech Republic

E-mail:dvorak@geonika.cz

\author{
${ }^{3}$ Ústav regionálního rozvoje a veřejné správy ${ }^{3}$ Dep. of Reg. Development and Public \\ Fakulta regionálního rozvoje a mezinárodnich studii Administration, Faculty of Reg.Development and \\ Mendelova univerzita $v$ Brně International Studies \\ Mendel University in Brno \\ $\triangle$ Tř́da Generála Píky 2005/7, 62800 Brno, Czech Republic \\ E-mail: petr.klusacek@mendelu.cz \\ ${ }^{4}$ Katedra biologických disciplín $\mid{ }^{4}$ Department of biological disciplines \\ Zemědělská fakulta Faculty of Agriculture, \\ Jihočeská univerzita v Českých Budéjovicich University of South Bohemia \\ $\bowtie$ Studentská 13, 37005 České Budéjovice, Czech Republic \\ E-mail:josefnav@gmail.com \\ ${ }^{5}$ School of Geography \\ Earth and Environmental Sciences \\ University of Birmingham \\ Edgbaston, Birmingham B15 2TT, United Kingdom \\ E-mail:d.vanderhorst@bham.ac.uk
}

\footnotetext{
Anotace

Význam energie generované z obnovitelných zdrojů v České republice neustále stoupá. Jedním ze sektorů obnovitelných zdrojů energii, který se v poslednich letech dynamicky rozviji, je produkce
} 
bioplynu. Počet bioplynových stanic a jejich instalovaný výkon zaznamenal vposlední dekádě dramatický rüst (z 11 instalaci o výkonu 4,19 MW v roce 2002 na 481 instalacís výkonem $363 \mathrm{MW}$ $v$ roce 2013). Je nepochybné, že fungováni bioplynových stanic, stejně jako ostatnich typů zařizení využivajicich obnovitelné zdroje (větrné elektrárny, solárni elektrárny atd.), přináši jako alternativa vůči vyčerpatelným fosilním zdrojüm řadu pozitiv. Nicméně s jejich lokalizaci, realizací, $i$ samotným provozem je spojena řada problémů, které mají významný vliv jak na kvalitu života dané obce, tak i na prostorové vztahy v rámci obce či vzhled krajiny. Tento př́spěvek se zabývá sociálnè-prostorovými aspekty obnovitelných zdrojů energie se zaměrením na bioplynové stanice a jejich akceptaci obyvatelstvem na lokální úrovni. Problematika je diskutována na př́kladu České republiky se zaměřením na faktory, které ovlivňuji míru akceptace tohoto typu obnovitelných zdrojů energií. Jako připadová studie bylo provedeno dotaznikové šetření zaměrené akceptaci mistni bioplynové stanice mistnim obyvatelstvem vobci Stonava (Moravskoslezský kraj), kde bylo provedeno dotaznikové šetření. Rovněž byla analyzována samotná bioplynová stanice, jeji vstupy, výstupy, jejich využití a samotný proces plánování, realizace i provozu tohoto projektu. Pozornost je věnována zejména souvislostem soužití venkovského obyvatelstva a bioplynové stanice.

\section{Klíčová slova}

obnovitelné zdroje energie, bioplyn, akceptace, venkov

\section{Annotation}

Importance of energy generated from renewable sources has been recently constantly increasing. One of sectors where huge development has been experienced is anaerobic digestion plants sector (biogas stations). Its number and installed capacities have dramatically risen in last decade in the Czech Republic (11 installations with 4,19 MW in 2002, 481 installations with $481 \mathrm{MW}$ in 2013). There is no doubt that operation of anaerobic digestion plants, alike other types of renewable sources of energy (wind power plants, solar power plants etc.), yields as alternative to non-renewable fossil sources plenty of positives. However problems are linked to renewable energy projects too. Such problems are connected to its location, realisation and operation of such facilities that might have important impact on both quality of life, landscape character and spatial relations within municipality. This contribution deals with socio-spatial aspects of renewable sources of energy with focus on anaerobic digestion plants and their acceptance by population on local level. This problem is discussed on example of the Czech Republic and is focused on factors that influence level of acceptance of this type of renewable sources of energy. As case study anaerobic digestion plant in Stonava municipality (Moravian-Silesian Region) was chosen where questionnaire survey with local population was carried out. Also parameters of Stonava anaerobic digestion plant are being analysed from the point view of its inputs, outputs, its use, planning process, incentives and operation of this facility. Attention has been primarily paid to consequences of coexistence of rural population and anaerobic digestion plant.

\section{Key words}

renewable sources of energy, biogas, acceptance, rural regions

JEL classification: $Q 2$

\section{Úvod}

Předkládaný př́spěvek se ve své první části věnuje teoretickým aspektům a předpokladům akceptace obnovitelných zdrojů energie se zaměřením na venkovský prostor. Na př́kladu případové studie bioplynové stanice ve Stonavě jsou diskutovány pozitivní př́nosy, bariéry či negativní dopady fungování takového typu zdroje obnovitelné energie ve venkovském prostoru. 


\section{Teoretická východiska}

Rozvoj venkova je značně neurčitým souslovím, jehož obsah je silně ovlivněn subjektivními názory jednotlivých skupin či individuálních obyvatel rurálního prostoru (Navrátil et al., 2010). Stejně jako existuje rozsáhlý počet nejrůznější typů či variant venkova (viz např́klad Perlín et al., 2010), existuje i široká škála individualizovaných preferencí vůči jednotlivým fenoménům, procesům či rozvojovým projektům, které jsou na venkově realizovány. Pokud náš pohled zúžíme na rozvojové projekty, měla by panovat obecná elementární shoda nad skupinou projektů, které mají ambici být považovány za veřejně prospěšné. Navzdory velmi vágnímu a nutno podotknout i velmi subjektivnímu vymezení tohoto pojmu (viz např́klad Sieber, 2005) lze předpokládat, že mezi takovýto typ projektů by měly být řazeny i projekty, které podporují využívání obnovitelných zdrojů energií jako je energie slunce, větru, vody, geotermální energie či energie vyrobená z biomasy. Faktem však zůstává, že i tyto projekty (a často i jejich plánování) vyvolávají kontroverze, které jsou způsobeny jak exogenními, tak i endogenními faktory. Zatímco exogenní faktory, jako jsou nevhodně koncipovaná dotační politika státu (či regionu), nejasná legislativa na podporu obnovitelných zdrojů či volba nevhodné technologie, lze z pohledu místního obyvatelstva považovat za stěží ovlivnitelné, s faktory endogenními (akceptace/odmítnutí projektu, jeho umístění, podceňování údržby či nedodržování technologických postupů) lze pracovat prostřednictvím konkrétních opatření na místní úrovni. A právě akceptaci daného projektu místním obyvatelstvem je možné považovat za klíčový endogenní faktor, který zásadně ovlivňuje, zda bude takovýto projekt realizován či nikoli.

Je všeobecně známým faktem, že fosilní zdroje energetických surovin (ropa, uhlí, zemní plyn) jsou zdroji vyčerpatelnými, jejichž využívání je zpravidla doprovázeno negativními externalitami jako je znečištěné životní prostředí (viz bliže např́iklad Otáhal, 2009), snížená kvalita života místního obyvatelstva (Pasten a Santamarina, 2012) či snížený potenciál pro cestovní ruch (Frantál a Kunc, 2011). Dalším trendem, který nehovoří ve prospěch spalování fosilních zdrojů surovin, je klimatická změna a globální oteplování (Turton a Barreto, 2006). Z výše uvedeného by měla vyplývat významná podpora veřejnosti vůči využivání obnovitelných zdrojů energie. Nicméně realita je poněkud složitější. Energie vyrobená z obnovitelných zdrojů je v podmínkách Evropské unie oproti klasickým energetickým zdrojům finančně náročnější a je proto nutná její podpora z veřejných rozpočtů, což budí časté kontroverze (Jacobsson et al., 2009). Rovněž lokalizace projekti̊ některých typů obnovitelných zdrojů má svá nečekaná úskalí, jakkoli by se mohlo zdát, že s ohledem na jejich omezený plošný rozsah (např́klad spalovny biomasy či bioplynové stanice) v porovnání s klasickými zdroji (doly, tepelné elektrárny, ropná pole, jaderné elektrárny) nemají konkurenci. Rovněž jejich relativně jednoduchá demontáž (solární elektrárny) ve srovnání s masivními mnohahektarovými areály, kde jsou zpracovávány klasické suroviny, se zdá být na první pohled výhodou. Do hry však vstupují jiné faktory, které realizaci projektů zásadně ovlivňují (Van der Horst, 2006, 2007, 2009). S postupující deindustrializací společnosti, která se primárně projevuje jako přesun pracovní síly z průmyslu do služeb (Corden a Neary, 1982), se razantně proměňuje vnímání místa obyvatelstvem, a to at' už obyvatelstvem místním či turisty. Projekty, které ještě před několika dekádami budily nadšení široké veřejnosti nad svou technickou dokonalostí (stavby přehrad, továren, bloků jaderných elektráren atd.), jsou dnes posuzovány zcela jinou optikou. Narušení krajinného rázu (např. větrnými elektrárnami), zastavování zemědělské půdy (např. solárními elektrárnami), pěstování zemědělských plodin pro energetické účely (spalování biomasy) či lokace provozů do zástavby obce (např. bioplynové stanice) - to jsou fenomény, se kterými obnovitelné zdroje navzdory své prospěšnosti úzce souvisí a které budí kontroverze mezi veřejností. Je proto nezbytně nutné, aby akceptaci obnovitelných zdrojů místním obyvatelstvem a lokaci těchto projektů byla věnována zvýšená pozornost, a aby byly tyto jevy podrobně zkoumány.

K tématu akceptace obnovitelných zdrojů energie již v současné době existuje relativně obsáhlá odborná literatura. Faktorům, které ovlivňují prostorové rozmístěných větrných elektráren v ČR, se věnuje např́klad Cetkovský a Nováková (2009), Frantál a Kučera (2009) nebo Frantál a Kunc (2010), širši rámec prostorových vztahů, environmentálních a socio-ekonomických souvislostí větrné energetiky zkoumá např́íklad Cetkovský et al. (2010). Faktory akceptace větrných (v Dánsku a Indii) a solárních elektráren (v Německu a USA) zkoumali a vzájemně hodnotili Sovacool a Ratan (2012), 
př́klady akceptace dvou typově odlišných projekti̊ na výroby obnovitelné energie v Německu se zabývali Musall a Kuik (2011). Nejzajímavějším z pohledu konceptuálního zakotvení problematiky je článek zacílený na využívání obnovitelných zdrojů z pohledu prospěšnosti pro obyvatelstvo na komunitní/obecní úrovni (Walker a Devine-Wright, 2008). Autoři diskutují jednotlivé varianty, př́nosy i dopady jednotlivých typů vlastnictví projektů zdrojů obnovitelných energií (na ose $\mathrm{X}$ soukromé vs. kolektivně vlastněné projekty - viz obrázek 1), hodnotí i proces prŕípravy projektů (na ose $\mathrm{Y}$ - otevřený vs. uzavřený proces př́pravy projektů, participace veřejnosti atd.), aby došli k závěru, že obecně nejprospěšnější (a nejsnáze akceptované veřejností) projekty realizace obnovitelných zdrojů jsou takové, jež jsou kolektivně vlastněny lokálními aktéry a na jejichž procesu př́pravy projektu participovala veřejnost, která měla možnost tvorbu projektu ovlivnit (sektory $\mathrm{A}, \mathrm{B}$, C ve schématu - obrázek 1).

Obr. 1: Varianty př́pravy a realizace projektů obnovitelných zdrojů energii z pohledu participace v plánovacím procesu a výsledného prrínosu pro lokální komunitu

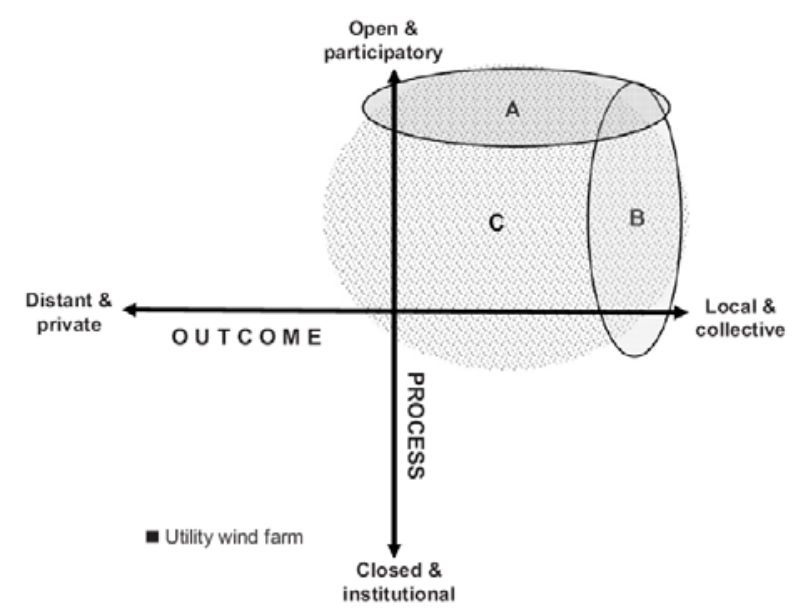

Zdroj: Walker a Devine-Wright (2008)

Z pohledu využívání bioplynu lze k výše uvedenému schématu diskutovat nad možností připojení třetí osy (osy Z), která by znázorňovala ve své částí nad osou $\mathrm{X}$ majoritní využívání odpadů ze zemědělských činností, odpadů z potravinářství či čističek odpadních vod jako vstupů do bioplynových stanic, v části pod osou $\mathrm{X}$ pak využívání vstupů jako jsou zemědělské plodiny (kukuřice, obilí) s ohledem kontroverze, které bývají vyvolávány při jejich využívání takovýmto způsobem. Vymezené sektory pro ideální projekt by $\mathrm{v}$ tomto př́ípadě byly poněkud zúženy. Tyto kontroverzní otázky ve svých studiích široce rozebírá např́klad Jørgensen et al. (2012) či Roberts et al. (2013).

Široce diskutovaným konceptem dotýkajícím se akceptace obnovitelných zdrojů je rovněž tzv. NIMBY syndrom (Wolsink, 2000), jehož podstatu lze vysvětlit jako postoj obyvatelstva, které na globální, národní či regionální úrovni veřejně prospěšné projekty podporují, nicméně na úrovni lokální, v blízkosti svých obydlí, je však odmítají (NIMBY - Not-In-My-Backyard). Mnohem intenzivnější, až absurdní variantou výše uvedeného, je syndrom známý pod akronymem BANANA (Buit-Absolutely-Nothing-Anywhere-Near-Anyone), který v principu odmítá výstavbu čekoholi (Cossu, 2006). Koncept v podmínkách České republiky na př́kladu větrných elektráren zkoumal např́klad Frantál (2008) nebo Frantál a Kunc (2010, 2011).

\section{Př́padová studie: bioplynová stanice Stonava}

Bioplynová stanice ve Stonavě, jejíž provoz, vliv na své okolí a její akceptace lokální veřejností byla předmětem předkládaného výzkumu, se rozkládá v jižní části katastru dané obce mimo její zastavěné partie v místní části Smolkovec. Samotná obec Stonava s 1828 obyvateli (k 1. lednu 2012) se nachází na ploše $13,86 \mathrm{~km}^{2}$ v Moravskoslezském kraji ve východním cípu ostravské aglomerace cca $8 \mathrm{~km}$ jihozápadně od Karviné. Území obce je značně postiženo projevy intenzivních důlních činností (existence terénních poklesů, hald, odkališt'), které zde probíhají již více než 150 let (důlní pole OKD, 
a.s., resp. dolů Darkov a ČSM zasahují na katastr obce). Vliv hornictví se výrazně projevuje i v sociální struktuře obyvatel. Velká část obyvatel obce vyjíždí za prací mimo obec a je zaměstnána v provozech výše uvedeného dolu.

Zkoumaná bioplynová stanice je v provozu od roku 2009 (s kapacitou 537 KW), kdy byla její výstavba dokončena, o rok později byla její kapacita více než zdvojnásobena na současnou instalaci ve výši $1380 \mathrm{KW}$. Stavba byla v obou zmíněných etapách spolufinancována z dotačních programů Ministerstva zemědělství ČR (Program rozvoje venkova) celkovou částkou 47,9 mil. Kč, vypracování dokumentace bylo podpořeno dotací krajského úřadu Moravskoslezského kraje. Je ve vlastnictví fyzické osoby a je provozována spolu se zemědělskou farmou s názvem Farma Stonava, která vznikla privatizací části Státního statku Karviná v 90. letech a zaměstnává přibližně 60 zaměstnanců (podrobnější informace k průběhu realizace stanice obsahuje tabulka 1).

Tab. 1: Časové milníky při plánování a realizaci bioplynové stanice Stonava

\begin{tabular}{|c|c|}
\hline 2006 & $\begin{array}{ll}\text { - } & \text { první úvahy o výstavbě bioplynové stanice } \\
\text { - } & \text { zvažování typu zařízení i výše kapacity }\end{array}$ \\
\hline 2007 & $\begin{array}{l}\text { - } \quad \text { dotace krajského úřadu Moravskoslezského kraje (dotační program př́́pravy } \\
\text { projektů v oblasti životního prostředí a zemědělství } \\
\text { - } \quad \text { rozhodnutí o vybudování zemědělské bioplynové stanice o elektrickém } \\
\text { výkonu } 500 \mathrm{KW} \text {, tepelném výkonu } 522 \mathrm{KW} \\
\text { - } \quad \text { dotace z Programu rozvoje venkova (SZIF) } \\
\text { - } \quad \text { územní a stavební ř́izení }\end{array}$ \\
\hline 2008 & - zahájení výstavby bioplynové stanice \\
\hline 2009 & - $\quad$ uvedení bioplynové stanice $(500 \mathrm{KW})$ do provozu \\
\hline 2010 & $\begin{array}{ll}\text { - } & \text { dotace z Programu rozvoje venkova (SZIF) } \\
\text { - } & \text { elektrický výkon bioplynové stanice navýšen na } 1381 \mathrm{KW} \text {, tepelný výkon } \\
& \text { na } 1313 \mathrm{KW} \text { a uvedeno do provozu }\end{array}$ \\
\hline
\end{tabular}

Co se týče typu, jde o bioplynovou stanici zemědělskou, která je pomocí materiálových vstupů a výstupů úzce propojena se zemědělskými aktivitami Farmy Stonava. Ta hospodaří na pozemcích o rozloze cca 650 hektarů, kde dominantní položkou osevních ploch je právě kukuřice (na téměř $30 \%$ rozlohy) pro potřeby bioplynové stanice (v roce 2011 bylo sklizeno cca 19000 tun kukuřice s tím, že osevní plochy kukuřice jsou v posledních letech neustále rozšiřovány). Jako vstupní materiál je rovněž používána prasečí kejda $\mathrm{z}$ vlastního velkokapacitního vepř́ína $\mathrm{s}$ kapacitou 2000 prasat, která by jinak zůstávala nevyužita. Časové proměny struktury vstupních materiálů do bioplynové stanice v období před a po navýšení instalace na současnou úroveň popisuje tabulka 2 . Z ní je patrné, že zatímco $\mathrm{v}$ původní variantě tvořily majoritu vstupy z chovu prasat, tedy prasečí kejda (více než dvě pětiny vstupů), po rozšíření bioplynové stanice je naopak dominantním zdrojem energie kukuřičná siláž (v současnosti tvoří téměř $50 \%$ vstupů). Pouze zhruba tříprocentní podíl na vstupech tvoří tráva jednak z vlastních zdrojů, nicméně v bioplynové stanici je zpracovávána i tráva posečená na pozemcích obce. Pro zajištění plynulého a bezproblémového provozu je nezbytné do bioplynové stanice denně dodávat průměrně 35-40 tun vstupů $\mathrm{v}$ dané struktuře. Uvedenou strukturu vstupů do bioplynové stanice lze považovat za více méně neměnnou, nebot' př́padné změny struktury vstupů mohou vyvolat technologické problémy provázené úniky zapáchajících látek.

Výstupy sledované bioplynové stanice jsou naznačeny v tabulce 3 . Vedle energetických výstupů ve formě elektrické energie $(8,2 \mathrm{MW} / \mathrm{rok})$ a tepla $(8,5 \mathrm{MW} /$ rok $)$ je produkován také digestát (cca 22 tisíc $\mathrm{m}^{3}$ ročně), což je pozůstatek po fermentačním procesu, vznikající anaerobní fermentací při výrobě bioplynu v bioplynových stanicích (Marada et al., 2008), který je dále používán jako dusíkaté hnojivo na pozemcích, kde Farma Stonava hospodaří. Sama bioplynová stanice na svůj provoz spotřebovává okolo $70 \mathrm{KWh}$, zbylá energie je dodávána do rozvodné sítě ČEZ. Co se týče energie tepelné, v rámci farmy je využíváno cca $40 \%$ vyrobené energie (vytápění provozů, kanceláří atd.), malá část tepelné energie je dodávána několika blízkým rodinným domům (jako jistá forma kompenzace), ostatní energie je v současné době bez využití. Nicméně záměrem farmy do budoucna je jednak zvýšit 
instalaci bioplynové stanice, ale také více využívat vyprodukované teplo (rozšǐření vytápění rodinných domů v obci).

Tab. 2: Rámcové proměny vstupů bioplynové stanice ve Stonavě (2009-2012)

\begin{tabular}{|l|c|c|c|c|}
\hline \multirow{2}{*}{ vstupy } & \multicolumn{2}{|c|}{ varianta $500 \mathbf{K W}$} & \multicolumn{2}{c|}{ varianta $\mathbf{1 0 0 0} \mathbf{K W}^{\mathbf{1}}$} \\
\cline { 2 - 5 } & tun/rok & $\mathbf{\%}$ & tun/rok & $\mathbf{\%}$ \\
\hline prasečí kejda & 7030 & 42,1 & 7030 & 25,8 \\
\hline kukuřičná siláž & 6160 & 36,9 & 13240 & 48,6 \\
\hline travní senáž & 500 & 3,0 & 1000 & 3,7 \\
\hline cukrovarnické řízky & 3000 & 18,0 & 6000 & 22,0 \\
\hline celkem & $\mathbf{1 6 ~ 6 9 0}$ & $\mathbf{1 0 0}$ & $\mathbf{2 7} \mathbf{2 7 0}$ & $\mathbf{1 0 0}$ \\
\hline
\end{tabular}

Tab. 3: Rámcové proměny výstupů bioplynové stanice ve Stonavě (2009-2012)

\begin{tabular}{|l|c|c|c|c|}
\hline \multirow{2}{*}{ výstupy } & \multicolumn{2}{|c|}{ varianta $\mathbf{5 0 0} \mathbf{~ K W}$} & \multicolumn{2}{c|}{ varianta $\mathbf{1 0 0 0} \mathbf{~ K W}$} \\
\cline { 2 - 5 } & $\mathbf{K W h} / \mathbf{r o k}$ & $\mathbf{m}^{\mathbf{3}} / \mathbf{r o k}$ & $\mathbf{K W h} / \mathbf{r o k}$ & $\mathbf{m}^{\mathbf{3}} / \mathbf{r o k}$ \\
\hline elektrická energie & & & & - \\
\hline tepelná energie & 4100000 & - & 8200000 & - \\
\hline digestát & 4280400 & - & 8560800 & - \\
\hline
\end{tabular}

\section{Hodnocení dotazníkového šetření}

Dotazníkový výzkum orientovaný na akceptaci obnovitelných zdrojů energií se zaměřením na místní bioplynovou stanici a její vliv na okolí se ve Stonavě uskutečnil v první polovině března 2013. Celkem bylo v ulicích obce osloveno 120 respondentů (obyvatel obce starších 15 let), dotazník se podařilo vyplnit se 108 obyvateli ( 8 obyvatel dotazník nevyplnilo s tvrzením, že o existenci bioplynové stanice v obci neví). Samotný dotazník byl strukturován do 12 uzavřených otázek $\mathrm{s}$ tím, že vyplnění jednoho formuláře trvalo přibližně 10 minut. $\mathrm{V}$ tomto příspěvku je hodnocen pouze výběr otázek z výzkumu, omezíme se na výsledky pouze $7 \mathrm{z}$ nich. Respondenti byli vybíráni na základě semi-kvótního výběru s vědomím nezbytnosti přibližžení se vyvážené věkové, genderové struktuře obyvatel obce. Relativně méně dotazníků se podařilo shromáždit $\mathrm{v}$ př́ípadě věkové kategorie 26-35 let (pouze $5 \%$ ), naopak relativně sdílnější byli obyvatelé ve věkové skupině 46-55 let (41\% souboru).

Úvodní otázka šetření se týkala postoje obyvatelstva k projektu bioplynové stanice v době jeho plánování. Čtyřri pětiny respondentů se stavbou stanice v tomto období souhlasily, s vybudováním stanice tehdy naopak nesouhlasila pouze desetina respondentů, stejný podíl oslovených osob tvrdil, že o stavbě ve fázi přípravy nebyli vůbec informováni. Srovnáme-li tyto výsledky s následující otázkou, která se dotazovala názory na změny v obci v souvislosti s provozem stanice, zjišt'ujeme, že negativní hodnocení provozu bioplynové stanice je pocit’ováno pouze $5 \%$ respondentů, naopak třetina respondentů vnímá spíše změnu obce $\mathrm{k}$ lepšímu (viz obrázek 2). Tito respondenti nejčastěji svou odpověd' $\mathrm{v}$ nejrůznějších variantách komentovali tvrzením, že zápach $\mathrm{z}$ vepř́ína před výstavbou bioplynové stanice byl mnohem horší před zahájením provozu stanice či tvrzením, že díky stanici už není na první pohled znát, že zde funguje velkokapacitní vepřín. Uvedené lze dát také do souvislosti s faktem, že provozovatel stanice, Farma Stonava, je nejvýznamnějším zaměstnavatelem v obci, kde se míra nezaměstnanosti pohybuje okolo $11 \%$ (poslední dostupný údaj Ministerstva práce a sociálních věcí z prosince 2011), což je sice méně než v okrese Karviná (13\%), nicméně pořád výše, než byla průměrná míra nezaměstnanosti v České republice $(8,6 \%)$ v tomto období. Dalším faktorem, který mohl pozitivně ovlivnit respondenty, je neustálé rozšiřování obhospodařovaných pozemků $\mathrm{v}$ obci, které farma využívá zejména pro pěstování kukuřice na zeleno jako základního vstupu do své

\footnotetext{
${ }^{1}$ Plán na rozšíření bioplynové stanice je patrný již z dokumentace vlivu výstavby na životní prostředí z roku 2007, kdy však bylo plánováno navýšení instalovaného výkonu na $1000 \mathrm{KW}$ (později však došlo k významnějšímu posunu na $1380 \mathrm{KW}$ ).
} 
bioplynové stanice. Lze předpokládat, že místní obyvatelstvo emočně lépe vnímá pozemky, kde jsou aktivně obhospodařovány, než pozemky ponechané ladem. Dalším z atributů pozitivního vnímání bylo tvrzení, že bioplynová stanice znamená zvýšení př́ijmů zemědělců. Výše zmíněných $5 \%$ respondentů, kteří bioplynovou stanici vnímají negativně, se rekrutovalo především $\mathrm{z}$ obyvatel žijících v bezprostřední blízkosti provozu. Na tomto místě je nezbytné uvést, že rodinné domy lokalizované v blízkosti bioplynové stanice jsou jako jistá forma kompenzačního opatření napojeny na bioplynovou stanici, která jim teplo dodává zdarma. Rovněž můžeme konstatovat, že negativní postoj vůči bioplynové stanici se před a po její výstavbě propadl o přibližně polovinu, což lze komentovat počáteční skepsi části obyvatel obce, která se však následně v průběhu provozu stanice nepotvrdila.

\section{Obr. 2: Názor obyvatel Stonavy na změny v obci v průběhu fungování bioplynové stanice}

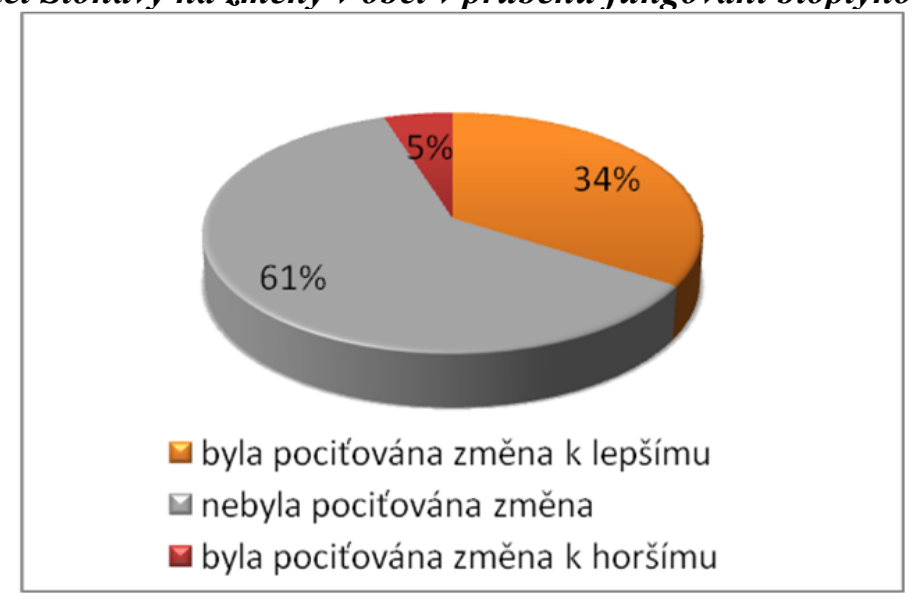

Zdroj: dotazníkové šetrení autorů, vlastní zpracování (n=108)

Hodnotící dotazy zajímající se o provoz stanice a její vliv na obec následovaly i v dalších otázkách. Při dotazu na ovlivnění životního prostředí v obci bioplynovou stanicí se ve větší míre projevily negativní aspekty tohoto provozu. Více než třetina respondentů si myslí, že životní prostředí provozem bioplynové stanice ovlivněno je. Na tomto místě můžeme spekulovat, zda se jedná o důsledek občasných technologických závad bioplynové stanice, zvýšení provozu nákladních vozidel v obci v souvislosti s každodenním navážením vstupních materiálů nebo jde o důsledek změn struktury osevních ploch v obci. Proti této hypotéze hovoří lokalizace stanice mimo intravilán obce, nicméně fakt, že provoz obcí byl zvýšen, je nepochybný. Rovněž zintenzivnění zemědělských aktivit $\mathrm{v}$ obci $\mathrm{v}$ souvislosti $\mathrm{s}$ rozšiřováním pěstování kukuřice pro bioplynovou stanici lze vnímat negativně (zvýšení prašnosti z polí, už zmíněná vyšší intenzita dopravy, souvislosti hnojení polí digestátem, vyšší riziko eroze atd.).

Další otázky výzkumu směřovaly na př́nosy a dopady provozu stanice. Zadání obou těchto otázek nabízelo na výběr množství konkrétních tvrzení, které se týkaly jak pozitivních př́nosů, tak i negativních dopadů. Jednotlivé varianty odpovědí byly respondenty hodnoceny na standardní škále názorů od varianty „určitě nesouhlasím“ po variantu „určitě souhlasím“. Každá z 5 možných odpovědí byla hodnocena pomocí bodů od varianty nejmenší prínos pro obec ( 1 bod), neutrální prínos ( 3 body) až po největší prŕnos pro obec (5 bodů), body pro jednotlivé odpovědi byly poté načítány do celkového skóre s možností dosažení skóre v rozmezí 100 až 500. Jak vyplývá z obrázku 3, za nejvíce pozitivní př́nos bylo označeno tvrzení, že bioplynová stanice vyrábí čistou a obnovitelnou energii a přispívá k ochraně životního prostředí (druhé tvrzení v pořadí). S odstupem deseti bodů získaly relativně vysoká skóre také tvrzení o využití surovin, které by jinak zůstaly bez užitku (prasečí kejda, tráva) či tvrzení, že bioplynová stanice představuje nové pracovní př́ležitosti. Na opačné škále pozitivních přínosů se umístilo tvrzení o zajímavosti bioplynové stanice pro př́padné turisty. 


\section{Obr. 3: Pozitivní př́nosy a negativní dopady provozu bioplynové stanice ve Stonavě}

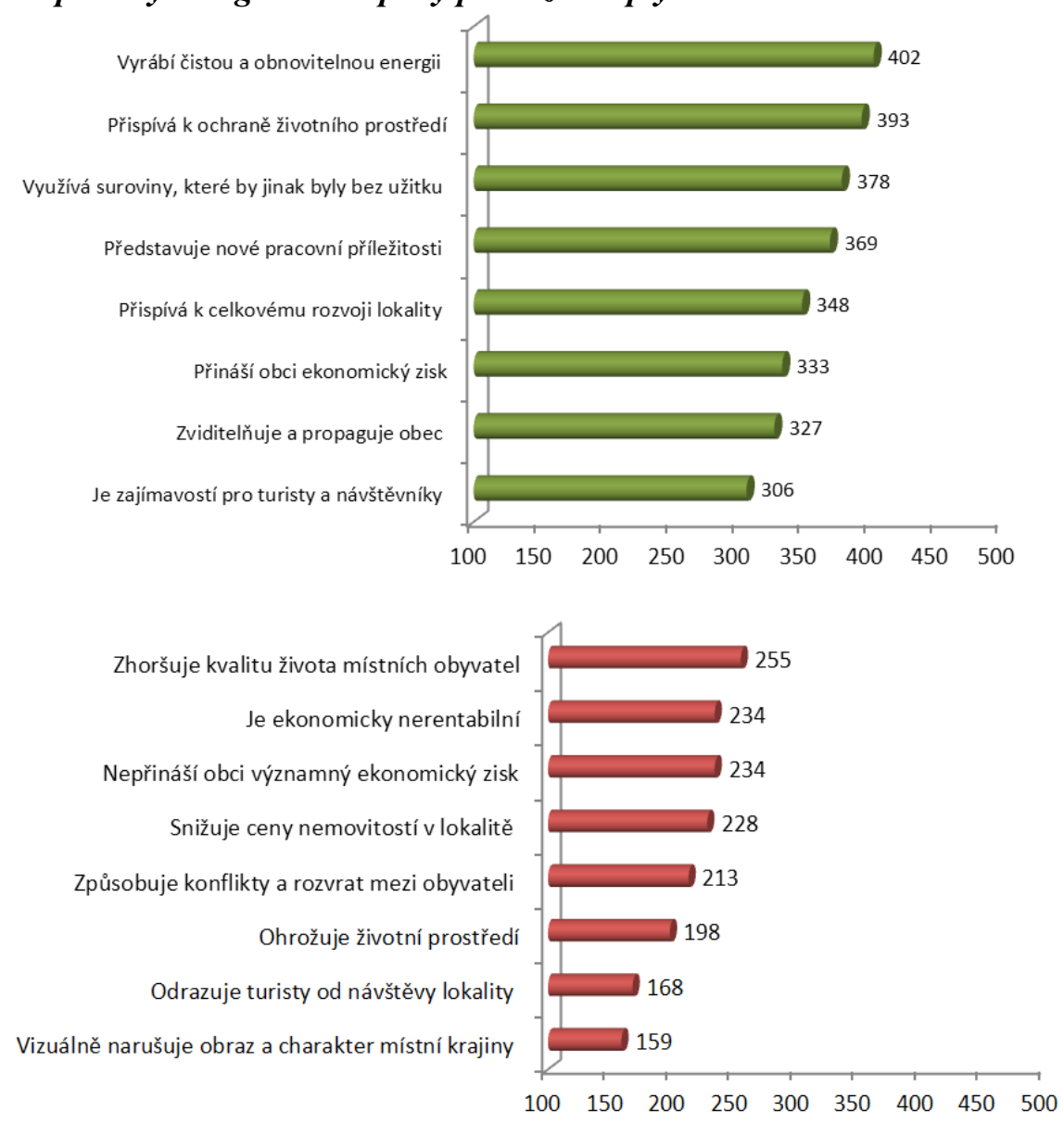

Zdroj: dotaznikové šetření autorů, vlastní zpracování (n=108)

Na negativní dopady provozu bioplynové stanice v obci se dotazovala další otázka (viz obrázek 3). Zde respondenti opět bodovali jednotlivá tvrzení o potenciálních dopadech, tentokrát negativními body. Každá z 5 možných odpovědí byla hodnocena pomocí negativních bodů od varianty nejméně negativní dopad pro obec (1 bod), neutrální dopad (3 body) až po nejvýznamnější negativní dopad na obec ( 5 bodů), body pro jednotlivé odpovědi byly poté načítány do celkového skóre, opět s možností dosažení skóre v rozmezí 100 až 500 . Bodové hodnocení je tedy srovnatelné s bodováním př́nosů (viz výše). Jako nejvýznamnější negativní dopad bylo s předstihem hodnoceno zhoršení životního prostředí v obci (hluk, špína), následováno negativním dopadem ve formě ekonomické nerentability provozu, omezeného ekonomického významu pro obec a snižováním ceny nemovitostí v lokalitě. Naopak za nejméně významně negativní dopady bylo označeno vizuální narušení obrazu krajiny stavbou bioplynové stanice, s odstupem pak negativní vliv na cestovní ruch.

Lze konstatovat, že hodnocení př́nosů i dopadů sledované bioplynové stanice nepřineslo nijak překvapující výsledky, nicméně za pozornost stojí např́íklad relativně nízká výše bodování pro negativní dopady. Tato nijak významná kritičnost obyvatelstva vůči stanici by mohla svědčit o vysoké míře sžití obyvatelstva s tímto provozem. Zdá se, že akceptace bioplynové stanice je mezi obyvateli Stonavy relativně vysoká, což však lze spíše označit jako formu lokální podpory místní zemědělské farmě, než podporu produkce obnovitelných zdrojů v obci. Diskutovat je rovněž možné nad faktem, že farma jako celek je významným zaměstnavatelem v obci (nicméně v samotné bioplynové stanice pracují pouze 2 zaměstnanci), což výrazně zvyšuje její obraz v obci. Může se zde také projevovat fenomén typický pro území postižená dlouhodobou industriální či těžební činností, a to koexistence zaměstnání obyvatelstva v průmyslu s provozováním vlastních zemědělských aktivit (tzv. 
kovozemědělci), což by mohlo svědčit o vyšší míře pochopení pro zemědělské aktivity a jejich souvislosti (hluk, zápach atd.). Rovněž vysoce pozitivně působí aktivní hospodaření farmy na pozemcích $\mathrm{v}$ rámci obce, které dř́íve ležely ladem, případně i fakt, že farma i stanice je vlastněna místním občanem. Rozhodujícím faktorem je však pravděpodobně skutečnost, že výstavbou bioplynové stanice byl významně omezen zápach šǐrící se z velkokapacitního vepřína, jímž byla obec dřive typická. Kontroverze spojené s fungováním zemědělské bioplynové stanice nebyly ve zkoumaném území ve větší míre zaznamenány, žádný z respondentů nezmínil etický problém související s využíváním zemědělských plodin pro nepotravinářské, tedy energetické účely.

\section{Závěr}

Akceptaci projektů realizujících zdroje obnovitelných energií veřejností lze označit za typ samoregulačního mechanismu, jímž jsou eliminovány projekty, které vzbuzují zvýšené ekonomické, sociální či environmentální kontroverze. Samozřejmě za předpokladu, že přípravné fáze projektů jsou dostatečným způsobem otevřené a transparentní tak, aby zainteresované obyvatelstvo mohlo své připomínky $\mathrm{v}$ rozhodovacím procesu uplatnit. A pochopitelně je rovněž otázkou, nakolik je aktivní participace lokálního obyvatelstva standardní výbavou sociálního kapitálu obcí České republiky či jen předpokladem, který je očekáván, nicméně častokrát ne ideálně naplněn. Svou roli sehrává i špatná reputace obnovitelných zdrojů energií v České republice, která je způsobena především nekoncepční subvenční politikou státu.

V souvislosti se závazkem České republiky vůči Evropské unii, který hovoří o 13,5 \% energie vyrobené z obnovitelných zdrojů v roce 2020 (Národní akční plán České republiky pro energii z obnovitelných zdrojů, 2010), lze předpokládat další dynamický rozvoj sektoru bioplynových stanic. Otázkou zůstává, jak tento bioplynový boom řídit a regulovat, aby byl dosažen konsenzus mezi nespornými př́nosy pro globální životní prostředí a př́padnými negativními dopady na místní obyvatelstvo. Akceptace takovýchto projektů lokální veřejností je nezbytným předpokladem pro budování i následný provoz projektů na realizaci obnovitelných zdrojů energií. Lze konstatovat, že v souvislosti s nepř́lilš dobrým obrazem obnovitelných zdrojů energie mezi veřejností České republiky jsou bioplynové stanice vnímány více jako přivýdělek zemědělců, než př́íspěvek k ochraně globálního životního prostředí a klimatu. Co se týče případové studie, bylo ověřeno, že bioplynová stanice ve Stonavě je relativně vysoce akceptována místní veřejností a nebudí tak výrazné kontroverze.

\section{Literatura}

[1] CETKOVSKÝ, S., NOVÁKOVÁ, E. Assesment of the impact of wind turbines on landscape character: implications for landscape planning. Moravian Geographical Reports, 2009, 17, 2: 2834.

[2] CETKOVSKÝ, S, FRANTÁL, B., ŠTEKL, J., et al. Větrná energie v České republice: hodnocení prostorových vztahů, environmentálních aspektů a socioekonomických souvislostí. Studia Geographica, 2010, 101. Ústav geoniky AV ČR, Brno, 209.

[3] CORDEN, W. M., NEARY, J. P. Booming sector and de-industrialisation in a small economy. Seminar Paper No. 195, University of Stockholm, 1982, 39.

[4] COSSU, R. Driving forces in national management strategies. Waste Management, 2006, 29: 2797-2798.

[5] FRANTÁL, B. Větrné elektrárny a NIMBY syndrom: analýza faktorů ovlivňujících vnímání a postoje obyvatel k rozvoji využití větrné energie. In Udržitelná energie a krajina. Veronica, Hostětín, 2008, s. 21-26.

[6] FRANTÁL, B., KUČERA, P. Impacts of the operation of wind turbines as perceived by residents in concerned areas. Moravian Geographical Reports, 2009, 17, 2: 35-45.

[7] FRANTÁL, B., KUNC, J. Factors of the uneven regional development of wind energy projects (a case of the Czech Republic). Geografický Časopis / Geographical Journal, 2010, 62, 3: 183201. 
[8] FRANTÁL, B., KUNC, B. Wind turbines in tourist landscape: Czech experience. Annals of Tourism Research, 2011, 38, 2: 499-519.

[9] JACOBSSON, S., BERGEK, A., FINON, D., LAUMER, V., MITCHELl, C., TOKE, D., VERBRUGGEN, A. EU renewable energy support policy: Faith or facts? Energy Policy, 2006, 37, 6: 2143-2146.

[10] JØRGENSEN, M. S., ANDERSEN, B. H., CASCAVAL, D. The controversies over bioenergy in Denmark:'bio'is not the same as' sustainable'. Environmental Engineering and Management Journal, 2012, 11, 11: 2101-2119.

[11] MARADA, P., VEČEŘOVÁ, V., KAMARÁD, L., DUNDÁLKOVÁ, P., MAREČEK, J. Př́ručka pro nakládání s digestátem a fugátem. Brno: Mendelova univerzita v Brně, 2008, 30.

[12] MUSALL, F. D., KUIK, O. Local acceptance of renewable energy - A case study from southeast Germany. Energy Policy, 2011, 39, 6: 3252-3260.

[13] Národní akční plán České republiky pro energii z obnovitelných zdrojů. Praha: Ministerstvo průmyslu a obchodu ČR, 2010, 97.

[14]NAVRÁTIL, J., PÍCHA, K., HŘEBCOVÁ, J. The importance of historical monuments for domestics tourists: The case of South- Western Bohemia (Czech Republic). Moravian Geographical Reports, 2010, 18, 1: 45-61.

[15] OTẢHAL, T. Problém zastoupení v institucionální ekonomii. Politická ekonomie, 2009, 57, 5: 677-695.

[16]PASTEN, C., SANTAMARINA, J. C. Energy and quality of life. Energy Policy, 2012, 49: 468476.

[17] PERLÍN, R., KUČEROVÁ, S., KUČERA, Z. Typologie venkovského prostoru Česka. Geografie, 2010, 115, 2: 161-187.

[18] ROBERTS, T., UPHAM, P., BOUCHER, P., MCLACHLAN, C., MANDER, S., GOUGH, C., ABI GHANEM, D. (2013): Conclusions and a research agenda for the social science of energy supply controversy. In Roberts, T. et al. (eds). Low-carbon energy controversies. Abingdon: Routledge, 2013, s. 259-270.

[19] SIEBER, P. Investiční rozhodování a veřejně prospěšné projekty. Acta Oeconomica Pragensia, 2005, 13, 4: 62-79.

[20]SOVACOOL, B. K., RATAN, P. L. Conceptualizing the acceptance of wind and solar elektricity. Renewable and Sustainable Energy Reviews, 2012, 16, 7: 5268-5279.

[21] THIEMEL, J. Bioplynová stanice Stonava. Oznámeni podle zákona č. 100/2001 Sb., o posuzování vlivů na životní prostředí. Stonava: Informační systém Cenia, 2007, 48.

[22] TURTON, H., BARRETO, L. Long-term security of energy suply and climate change. Energy Policy, 2006, 34, 15: 2232-2250.

[23]VAN DER HORST, D. Spatial cost-benefit thinking in multi-functional forestry; towards a framework for spatial targeting of policy interventions. Environmental Economics, 2006, 59: 171-180.

[24] VAN DER HORST, D. NIMBY or not? Exploring the relevance of location and the politics of avoided opinions in renewable energy siting controversies. 2007.

[25] VAN DER HORST D. Spatial planning of wind turbines and the limits of 'objective' science. Moravian Geographical Reports, 2009, 17, 2: 46-51.

[26] WALKER, G., Devine-Wright, P. Community renewable energy: What shoud it mean? Energy Policy, 2008, 36: 497-500.

[27] WOLSINK, M. Wind power and the NIMBY-myth: institutional capacity and the limited significance of public support. Renewable energy, 2000, 21: 49-64.

Př́spěvek byl zpracován v rámci projektu OPVK pod názvem „Energetika v krajině: inovace, dynamizace a internacionalizace výzkumu" (CZ.1.07/2.3.00/20.0025). 